\title{
STUDI ANALISIS PENGARUH RAFA' (PEMERIKSAAN NIKAH) TERHADAP KEABSAHAN ADMINISTRASI DAN HUKUM PERKAWINAN MENURUT KEPUTUSAN MENTERI AGAMA RI. NO. 298, TAHUN 2003.
}

\author{
Abd. Basit Misbachul Fitri \\ STAI Darussalam Krempyang, Jl. KH. Wahid Hasyim No.126. Krempyang \\ Tanjunganom Nganjuk Jawa Timur \\ Email: abdbasitfitri@gmail.com
}

\begin{abstract}
Marriage is a religious order and is a worship, in the context of carrying out worship that is muamalah. Muamalah in Islam is highly recommended to record it in a State document that has legal force as the Decree of the Minister of Religion of the Republic of Indonesia. No. 298, 2003, to match the document data with the facts. Before the registration of marriage in the Office of Religious Affairs, it is necessary to do rafa '(examination of marriage to prospective brides) so that the data received is valid authentic away from lies and even hoak. The purpose of Rafa 'is nothing but an examination for the validation of the terms of marriage harmony in both the State administration and Islamic law. When there is a mismatch between the administrative data of marriage with the original and its personnel, then the marriage can be canceled by the KUA and even make the marriage invalid both according to positive law and Islamic law. Because deemed legal defects.
\end{abstract}

Keywords: Influence of Rafa (Marriage Examination), Administrative Validity, Marriage Law in Indonesia

\begin{abstract}
Abstraksi
Nikah adalah perintah agama dan merupakan ibadah, dalam rangka melaksanakan ibadah yang bersifat muamalah. Muamalah dalam Islam sangat dianjurkan untuk mencatatnya dalam dokumen Negara yang mempunyai kekuatan hukum sebagaimana Keputusan Menteri Agama RI. No. 298, Tahun 2003, agar sesuai antara data dokumen dengan faktanya. Sebelum pencatatan nikah di Kantor Urusan Agama, perlu dilakukan rafa' (pemeriksaan nikahterhadap Calon pengantin) agar data yang diterima valid otentik jauh dari kebohongan bahkan hoak. Tujuan adanya Rafa' tidak lain adalah pemeriksaan untuk validasi syarat rukun nikah secara baik administrasi Negara dan hukum Islam. Ketika terjadi ketidak sesuaian antara data administrasi nikah dengan aslinya dan personelnya, maka bisa dilakukan pembatalan nikah oleh KUA bahkan menjadikan tidak sahnya perkawinan baik menurut Hukum positif dan Hukum Islam. Karena dipandang cacat hukum.
\end{abstract}

Kata Kunci : Pengaruh Rafa' (Pemeriksaan Nikah), Keabsahan Administrasi, Hukum Perkawinan di Indonesia

\section{LATAR BELAKANG MASALAH}

Perkawinan adalah kehendak setiap manusia yang merupakan sunnah Rasul yang dianjurkan bagi seseorang yang istito'ah baik dlahir maupun batinnya, hikmah menikah utamanya adalah bernilai ibadah. ${ }^{1}$ Ikatan ini begitu mulia sehingga dalam al-Qur'an

\footnotetext{
${ }^{1}$ Tuntunan praktis rumah tangga bahagia, (Sudoarjo: Badan Penasihatan, pembinaan dan pelestarian perkawinan BP4. Prov. Jatim). H. 11.
} 


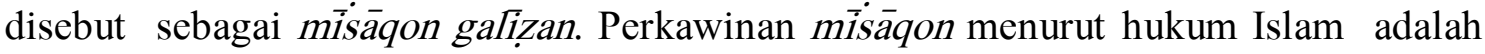
pernikahan, yaitu akad yang sangat sakral dilakukan di Kantor Urusan Agama, galizan adalah yang kuat, untuk mentaati perintah Allah dan melaksanakannya merupakan ibadah, perkawinan bertujuan untuk mewujudkan kehidupan rumah tangga yang sakinah, mawaddah dan rahmah. ${ }^{2}$

Indonesia adalah Negara Hukum, baik hukum Perdata dan Hukum Pidana, juga memuat hukum Pemerintahan, Hukum antar Agama dan hukum Islam sehingga Setiap kejadian hukum di Indonesia membutuhkan pencatatan administrasi, terkait dengan keabsahan hukum dan legalitas dokumen Negara. Hal ini sebagaimana al-Qur'an surat al-Baqarah [2] 282 :

Artinya; "Hai orang-orang yang beriman, apabila kamu bermu'amalah" tidak secara tunai untuk waktu yang ditentukan, hendaklah kamu menuliskannya. dan hendaklah seorang penulis di antara kamu menuliskannya dengan benar. dan janganlah penulis enggan menuliskannya sebagaimana Allah mengajarkannya, meka hendaklah ia menulis, dan hendaklah orang yang berhutang itu mengimlakkan (apa yang akan ditulis itu), dan hendaklah ia bertakwa kepada Allah Tuhannya, dan janganlah ia mengurangi sedikitpun daripada hutangnya".

Perkawinan adalah anjuran setiap agama, khususnya Agama Islam sebagaimana yang dicontohkan Rasulullah SAW, Untuk mewujudkan perkawinan yang sah secara hukum Islam dan hukum positif, maka membutuhkan Legalitas Hukum Perkawinan di Indonesia sebagaimana diatur ketetapan Pemerintah Negara Indonesia. Yaitu UndangUndang Perkawinan No. 1 tahun 1974 "tentang dasar dasar perkawinan" tertuang pada pasal 5 ayat (2) yang berbunyi: Perkawinan tersebut pada ayat (1) dilakukan oleh Pegawai Pencatat Nikah (Penghulu) sebagaimana yang diatur dalam Undang-undang No. 22 tahun 1946 jo Undang-Undang No. 32 1954. Juga dalam pasal 6 ayat (1) :"Setiap perkawinan harus dilangsungkan di hadapan dan dibawah pengawasan Pegawai Pencatat Nikah. Ayat (2) Perkawinan yang dilakukan diluar pengawasan Pegawai Pencatat Nikah tidak mempunyai kekuatan hukum. ${ }^{4}$

\footnotetext{
${ }^{2}$ Undang-Undang Perkawinan di Indonesia tentang, “Dasar-dasar Perkawinan”, Bab II pasal 2, 3, hal. 180 .

${ }^{3}$ Bermu'amalah ialah seperti berjualbeli, hutang piutang, atau sewa menyewa dan sebagainya (termasuk akad nikah).

${ }^{4}$ Keputusan Menteri Agama Republik Indonesia No. 154 Tahun 1991 tentang pelaksanaan Intruksi Presiden Republik Indonesia No. 1 Tahun 1991 tanggal 10 Juni 1991 Menteri Agama Indonesia. Dicetak dalam Undang-Undang Perkawinan di Indonesia tentang, “Dasar-dasar Perkawinan” Bab II pasal 5 ayat (2), dan pasal 6 ayat (1) dan (2), hal. 180-181.
} 
Sebelum terjadinya pencatatan nikah di Kantor Urusan Agama, Wajib dilaksanakan pemerikasaan nikah oleh PPN kepada calon pengantin dan Wali Nikah, dalam istilah Kantor Urusan Agama disebut Rafa'. Yakni Pemeriksaan terhadap calon suami, calon isteri dan wali nikah, dilakukan secara bersama-sama, tetapi tidak ada halangannya jika pemeriksaan itu dilakukan sendiri-sendiri. Bahkan dalam keadaan yang meragukan, perlu dilakukan pemeriksaan sendiri-sendiri. Pemeriksaan dianggap selesai, apabila ketiga-tiganya selesai diperiksa secara benar berdasarkan surat-surat keterangan yang dikeluarkan kepala Desa/lurah dan isntansi lainnya dan berdasarkan wawancara langsung dengan yang bersangkutan. Apabila pemeriksaan calon suami isteri dan wali itu terpaksa dilakukan pada hari-hari yang berlainan, maka kecuali pemeriksaan pada hari pertama, di bawah kolom tanda tangan yang diperiksa halaman 3 model NB ditulis tanggal dan hari pemeriksaan.

Pemeriksaan terhadap calon suami, calon isteri dan wali nikah ditulis dalam lembaran Daftar Pemeriksaan Nikah (Formulir Model NB), ruang II, III dan IV rangkap dua.

Hasil pemeriksaan dibacakan kembali dan jika diperlukan diterjemahkan ke dalam bahasa yang dimengerti oleh yang bersangkutan. Selanjutnya kedua lembar Model NB tersebut, pada halaman 3 ditanda tangani oleh yang diperiksa dan Pembantu PPN yang memeriksa. Sesuai pemeriksaan, surat-surat keterangan yang diperlukan dikumpulkan menjadi satu dengan lembar model NB kemudian dibuat pengumuman (Model NC). ${ }^{5}$

Adapun ketentuan Rafa'sebagaimana Keputusan Menteri Agama RI. No. 477 Tahun 2004 pasal 8 yaitu:

(1) Hasil pemeriksaan nikah ditulis dan ditandatangani oleh Penghulu atau Pembantu Penghulu dan mereka yang berkepentingan dalam daftar pemeriksaan nikah menurut model NB.

(2) Pemeriksaan nikah yang ditandatangani oleh Pembantu Penghulu diluar Jawa dibuat daftar pemeriksaan nikah rangkap dua, sehelai dikirim kepada Kantor Urusan Agama Kecamatan yang mewilayahinya beserta surat-surat yang

${ }^{5}$ Dirjen Bimais dan Penyelenggaraan Hajji, Pedoman Pembantu Pegawai Pencatat Nikah, (Jakarta : 2004), $8-9$. 
diperlukan selambat-lambatnya 15 (lima belas) hari kerja sesudah akad nikah dilaksanakan dan sehelai lainnya untuk arsip.

(3) Calon suami, calon isteri dan wali nikah, masing-masing mengisi daftar pemeriksaan nikah sebagaimana dimaksud pada ayat (1) kolom 1, 2 dan 3 sedangkan kolom yang lain diisi oleh Penghulu atau Pembantu Penghulu.

(4) Apabila mewakili tidak dapat menulis, maka kolom 1, 2, 3 dan 4 sebagaimana dimaksud pada ayat (3) diisi dan dibacakan oleh Penghulu atau Pembantu Penghulu.

(5) Apabila lembar pertama daftar pemeriksan hilang, maka oleh Pembantu Penghulu dibuat salinan dari daftar kedua dengan berita acara tentang sebabsebab hilangnya lembar pertama tersebut.

Juga disebutkan pada pasal 9 yaitu:

(1) Apabila calon suami atau wali nikah bertempat diluar wilayah Kantor Urusan Agama Kecamatan dan tidak dapat hadir untuk diperiksa, maka pemeriksaanya dilakukan oleh Penghulu atau Pembantu Penghulu.

(2) Penghulu atau Pembantu Penghulu sebagaimana dimaksud pada ayat (1), memeriksa calon suami atau wali nikah, kemudian mengirimkan daftar pemerikasaan kepada Penghulu atau Pembantu Penghulu ditempat pelaksanaan pernikahan.

(3) Apabila ternyata dari hasil pemeriksaan terdapat halangan pernikahan menurut hukum Islam atau peraturan perundang-undangan tentang perkawinan dan atau belum dipenuhinya persyaratan/ketentuan tersebut dalam pasal 7, maka hal tersebut segera diberitahukan kepada calon suami dan wali nikah atau wakilnya kepada Penghulu atau Pembantu Penghulu menurut model N-8.

Juga disebutkan pada pasal 10 yaitu:

(1) Calon suami isteri yang mengadakan perjanjian perkawinan perkawinan tidak boleh bertentangan dengan hukum Islam dan peraturan perundang-undangan.

(2) Perjanjian sebagaimana tersebut pada ayat (1) dibuat rangkap 4 diatas kertas bermaterai cukup menurut peraturan perundang-undangan; lembar pertama untuk suami, kedua untuk isteri, ketiga untuk Penghulu dan keempat untuk Pengadilan. 
(3) Perjanjian taklik talak bukan suatu perjanjian wajib diadakan pada setiap perkawinan, akan tetapi sekali taklik talak sudah diperjanjikan tidak dapat dicabut kembali.

(4) Suami yang mengikrarkan șigat taklik talak dianggap sah bila ditandatangani setelah akad nikah dilaksanakan.

(5) Șigat taklik talak ditetapkan oleh Menteri Agama.

(6) Dalam daftar pemeriksaan, dicatat ada atau tidak ada perjanjian perkawinan/taklik talak sebagaimana dimaksud pada ayat (1) dan ayat (3). ${ }^{6}$

Dalam Keputusan Menteri Agama Republik Indonesia No. 298 tahun 2003 Bab IV pada pasal 7,8 , tentang pemeriksaan nikah. ${ }^{7}$

Disebutkan pada pasal 7 yaitu:

"PPN atau Pembantu PPN yang menerima pemberitahuan kehendak nikah memeriksa calon suami, calon isteri, dan wali nikah tentang halangan pernikahan menurut model NB".

Yang dimaksud pemeriksaan Nikah sebagaimana dalam pasal 7 Disebutkan pada pasal 8 yaitu:

(1) Dalam melakukan pemeriksaan nikah diperlukan penelitian terhadap:

a) Surat keterangan untuk nikah menurut model $\mathrm{N}-1$.

b) Kutipan akan kelahiran atau surat kenal lahir, atau surat keterangan asal usul calon mempelai yang diberikan oleh Kepala Desa/pejabat setingkat menurut model N-2.

c) Persetujuan kedua calon mempelai menurut model N-3.

d) Surat keterangan orang tua (ibu bapak) dari Kepala Desa/pejabat setingkat menurut model N-4.

e) Izin tertulis orang tua bagi calon mempelai yang belum mencapai usia 21 tahun menurut model N-5.

f) Dalam hal tidak ada izin dari kedua orang tua atau walinya sebagaimana dimaksud huruf e diatas diperlukan izin dari Pengadilan;

\footnotetext{
${ }^{6}$ Keputusan Menteri AgamaRI. No. 477 Tahun 2004 tentang, "Pemeriksaan Kehendak Nikah”, Bab. IV pasal 7, 8, 9 dan 10, hal. 5, 6 .

${ }^{7} \mathrm{KHI}$.
} 
g) Dispensasi dari Pengadilan bagi calon suami yang belum mencapai umur 19 tahun dan bagi calon isteri yang belum mencapai umur 16 tahun.

h) Jika calon mempelai anggota TNI/POLRI diperlukan surat izin dari atasannya/kesatuannya.

i) Akta cerai atau buku pendaftaran talak/buku pendaftaran cerai bagi mereka yang perceraiannya terjadi sebelum berlakunya Undang-undang No. 7 tahun 1989.

j) Akta kematian atau surat keterangan kematian suami/isteri dibuat oleh Kepala Desa/lurah atau pejabat berwenang yang menjadi dasar pengisian model N-6 bagi janda/duda yang akan menikah.

k) Izin kawin dari kedutaan bagi warga negara asing.

Jika kutipan pendaftaran buku talak/buku pendaftaran cerai sebagaimana dimaksud dalam ayat (2) huruf (J) rusak atau hilang, maka dapat diminta duplikatnya atau keterangan lain sebagaimana diatur dalam pasal 37 ayat (1) Keput usan ini." Apabila buku nikah, kutipan buku pendaftaran talak, kutipan pendaftaran cerai, dan kutipan buku pencatatan rujuk hilang atau rusak, maka yang bersangkutan dapat meminta duplikat tersebut pada Penghulu Kantor Urusan Agama Kecamatan yang mengeluarkan menurut model DN, DT, DC dan DR".

Jikalau terjadi kekurangan atau cacat persyaratan Administrasi Pencatatan nikah, maka Kantor Urusan Agama berhak menolak pencatatan nikah atau penolakan kehendak nikah. Dalam Keputusan Menteri Agama Republik Indonesia No. 477 tahun 2004 tentang pencatatan nikah pada pasal 14 bab VI tentang penolakan kehendak nikah disebutkan beberapa hal yang menyangkut persyaratan secara administratif tentang proses pendaftaran nikah. Pasal 14 bab VI tentang penolakan nikah menjelaskan:

(1) Setelah diadakan pemeriksaan dan ternyata tidak memenuhi syarat-syarat yang telah ditentukan, maka Penghulu atau Pembantu Penghulu diharuskan menolak pelaksanaan pernikahan dimaksud, dengan memberikan surat penolakan kepada yang bersangkutan serta alasan penolakannya menurut model N-9.

(2) Terhadap penolakan sebagaimana dimaksud pada ayat (1), yang bersangkutan dapat mengajukan keberatan kepada pengadilan setempat. 
(3) Apabila Pengadilan memerintahkan pelaksanaan pernikahan, maka Penghulu atau Pembantu Penghulu diharuskan melangsungkan pernikahan. ${ }^{8}$

Oleh karena itu penelitian ini bertujuan untuk menjelaskan betapa pentingnya Rafa' (Pemeriksaan Nikah) yang dilakukan PPN di Kantor Urusan Agama sebelum dilaksanakan akad nikah adalah Dalam rangka untuk mencari kejalasan (Tabayyun) keberadaan baik status Calon Pengantin laki-laki maupun wanita sebagaimana data N1, asal-usul tertuang dalam N2, alamat calon pengantin dan orang tua, baik kandung maupun orang tua angkat, keberadaan calon pengantin, kesiapan dan kesanggupan persetujuan mereka menikah atas dasar suka sama suka atau paksaan sebagaimana dalam data N3, hakikat wali nikah yakni wali nikah sebenarnya sebagaimana urut-urutan wali dalam hukum Islam jumlah mahar ${ }^{9}$ (kegiatan upaya ke arah terjadinya hubungan perjodohan antara seorang pria dan wanita) yang diberikan oleh Calon suami kepada calon isteri agar tidak memberatkan suami. Melaui proses Rafa' (pemerikasaan) inilah PPN dan kesra mengetahui dan menemukan kejelasan (tabayyun) kcalon pengantin dan walinya, makanya melalui Keputusan Menteri Agama RI. No. 298 Tahun 2003. Oleh PPN kepada Calon pengantin dan Wali Nikah. Kesesuaian data dan fakta agar tidak terjadi pemalusan data, identitas, status, alamat bahkan wali Nikah. Karena selama ini banyaknya calon pengantin yang hoak sebagaimana surat Al-Hujurot [49] ayat 6 :

Artinya: "Hai orang-orang yang beriman, jika datang kepadamu orang Fasik membawa suatu berita, Maka periksalah dengan teliti agar kamu tidak menimpakan suatu musibah kepada suatu kaum tanpa mengetahui keadaannya yang menyebabkan kamu menyesal atas perbuatanmu itu”.

Berkas administrasi Calon pengantin atau data yang dikirim kepada Kantor Urusan Agama jika terjadi ketidakcocokan dengan aslinya/faktanya akan diketahui ketika diselenggarkan rafa’'(Pemeriksaan Nikah), maka dalam keadaan ini dikatakan cacat administrasi yang berpengaruh terhadap Keabsahan Administrasi dan Hukum Perkawinan di Indonesia sehingga mengakibatkan Kantor Urusan Agama berhak menolak pendaftaran perkawinan yang cacat administrasi.

\footnotetext{
${ }^{8}$ Keputusan Menteri AgamaRI. No. 477 Tahun 2004 tentang, "Penolakan Kehendak Nikah”,Bab.VI pasal 14, hal. 7.

${ }^{9}$ Abdurrohman al-Ghozi, Fiqh Munakahat, (Jakarta : Kencana, 2012) h. 73.
} 


\section{RUMUSAN MASALAH}

Berdasarkan latarbelakang tersebut, maka dapat dirumuskan beberapa pokok masalah sebagai berikut:

1. Apa yang dimaksud dengan Rafa'(Pemeriksaan Nikah)?

2. Bagaimana proses Rafa' (Pemeriksaan Nikah) oleh PPN terhadap calon pengantin dan wali nikah?

3. Bagaimana pengaruh Rafa' (Pemeriksaan Nikah) Terhadap Keabsahan Administrasi dan Hukum Perkawinan Keputusan Menteri Agama RI. No. 298 Tahun 2003 ?

\section{PENDEKATAN}

Dalam penyusunan ini penulis menggunakan pendekatan normatif-yuridis, pendekatan tersebut menggunakan hukum keabsahan pemeriksaan dan pencatatan perkawinan di Indonesia sebagaimana Keputusan Menteri Agama RI. No. 298 Tahun 2003. Oleh PPN kepada Calon pengantin dan Wali Nikah. Tentang Pengaruh Rafa' (Pemeriksaan Nikah) Terhadap Keabsahan Administrasi dan Hukum Perkawinan di Indonesia. Kemudian dianalisa dan komparasikan secara kritis. Adapun bahan kajiannya berasal dari observasi dan sumber kepustakaan yang antara lain buku-buku dan dokumen. Teknik pengumpulan data secara observasi. Pertama pengumpulan data melalui wawancara (Interview) dengan PPN (Pegawai Pencatat Nikah) di KUA. Kedua, dilakukan dengan melalui studi kepustakaan (library research). data yang diperoleh dari literatur yang berkaitan dengan persoalan yang dibahas dalam ini. Yakni istilah Rafa' (Pemeriksaan Nikah) yang dilakukan oleh PPN kepada calon pengantin pada hari sebelum pelaksanaan pencatatan dan Akad nikah. Pada proses rafa'Terjadi singkronisasi antara data administrasi (Nama, Alamat, Status, dan wali nikah calon pengantin), juga adanya pernyataan persetujuan antar catin, wali nikah serta kesanggupan penentuan nominal mas kawin pernikahan. jika dalam rafa' (pemeriksaan) tersebut sesuai antara admoinistrasi dan kenyataanya, maka akad nikah bisa dilangsungkan dan dikategorikan sesuai at uran undang-undang perkawian di Indonesia dan Keputusan Menteri Agama RI. No. 298, Tahun 2003. 
Analisis data menggunakan tahap content analisis, menganalisis proses administrasi dengan kenyataannya yakni calon pengantin dan wali nikah sebagaimana syarat rukun nikah dalam Islam, Kemudian analisa tersebut bertujuan unt uk menemukan dan mencermati 'Pengaruh Rafa' (Pemeriksaan Nikah) Terhadap Keabsahan Administrasi dan Hukum Perkawinan Menurut Keputusan Menteri Agama RI. No. 298 Tahun 2003.” Yang dilakukan Oleh PPN terhadap Calon pengantin dan Wali Nikah dan Hukum Islam .

\section{HASIL PENELITIAN}

Sebelum dilangsungkannya pencatatan akad nikah diKUA, ada Prosedur pendaftaran kehendak nikah di Kantor Urusan Agama sebagai berikut: ${ }^{10}$

1. Setiap penduduk yang akan melangsungkan perkawinan memberitahukan kehendaknya kepada Kantor Urusan Agama, baik secara lisan atau tertulis, oleh calon pengantin, atau oleh orang tua atau wakilnya dengan membawa beberapa persyaratan administrasi pendaftaran nikah.

2. Pemberitahuan tersebut memuat nama, umur, agama, pekerjaan, tempat kediaman calon pengantin dan apabila salah seorang atau keduanya pernah kawin, disebutkan juga nama isteri atau suami terdahulu.

3. Pemberitahuan tersebut dilakukan sekurang-kurangnya 10 (sepuluh) hari kerja sebelum perkawinan dilangsungkan.

4. Pengecualian terhadap jangkan waktu tersebut, disebabkan suatu alasan yang penting, diberikan oleh Camat atas nama Bupati Kepala Daerah Kabupaten Jombang.

5. Pegawai Pencatat yang menerima pemberitahuan kehendak nikah meneliti syarat-syarat perkawinan, apakah sudah dipenuhi dan apakah terdapat halangan perkawinan menurut Undang-undang.

6. Setelah diperiksa ternyata persyaratan pemberitahuan kehendak nikah sudah lengkap, dan tidak ada sesuatu halangan perkawinan, kemudian hasil penelitian tersebut ditulis oleh Pegawai Pencatat dalam sebuah daftar pencatatan nikah.

\footnotetext{
${ }^{10}$ Hasil wawancara peneliti dengan Kepala Kantor Urusan AgamaKecamatan Jombang Kabupaten Jombang.
} 
7. Pegawai Pencatat Nikah menyelenggarakan pengumuman tentang pemberitahuan kehendak melangsungkan perkawinan yang telah ditandatangani oleh Pegawai Pencatat nikah dengan cara menempelkan surat pengumuman menurut formulir pada tempat yang sudah ditentukan pada Kantor Urusan Agama dan mudah dibaca, yang memuat:

a. Nama, umur, agama, pekerjaan, tempat kediaman calon pengantin dan dari orang tua calon pengantin, apabila salah seorang atau keduanya pernah kawin disebutkan nama isteri atau suaminya terdahulu.

b. Hari, tanggal, jam dan tempat akad nikah dilangsungkan (biasanya akad nikah berada dikediaman calon pengantin wanita).

Perkawinan muslim di Indonesia dicatat oleh Pegawai Pencatat Nikah di Kantor Urusan Agama kecamatan, sedangkan masyarakat non muslim maupun perkawinan silang antara masyarakat muslim dengan non muslim dicatat oleh Pegawai Pencatat Nikah di Kantor Catatan Sipil. Akta perkawinan dibuat rangkap 2 (dua), helai pertama disimpan oleh Pegawai Pencatat Nikah di KUA, helai kedua disimpan pada Panitera Pengadilan Agama dalam wilayah Kantor Pencatatan Perkawinan itu berada. Suami Isteri masing-masing diberikan kutipan akta perkawinan. ${ }^{11}$ Kutipan akta nikah dicetak dalam dua warna, warna cokelat untuk suami dan warna hijau untuk isteri.

Akta nikah adalah akta perkawinan sebagai bukti keabsahan perkawinan. Sebagaimana dimaksud pasal 12 dan 13 Peraturan Pemerintah No. 9 Tahun 1975 tentang pelaksanaan Undang-undang No. 1 tahun 1974 tentang perkawinan. Sedangkan buku nikah adalah kutipan akta nikah yang ditandatangani oleh Penghulu. ${ }^{12}$

Proses adanya pemeriksaan, pengawasan dan pencatatan kutipan akta nikah di KUA Kecamatan jombang Kabupaten Jombang selama ini sudah cukup baik, jeli dan tepat sesuai dengan petunjuk pelaksanaan jabatan fungsional Penghulu sesuai dengan Keputusan Departemen Agama Republik Indonesia.

\footnotetext{
${ }^{11}$ Peraturan Pemerintah Republik Indonesia No. 9 Tahun 1975 tentang pelaksanaan Undang-Undang No. 1 Tahun 1974 tentang Perkawinan. Dicetak dalam Undang-Undang Perkawinan di Indonesia tentang “Akta Perkawinan"Bab IV pasal 13, hal. 46

12 Keputusan Menteri Agama RI No. 477 Tahun 2004 tentang "Pencatatan Nikah" Diterbitkan Seksi Urusan Agama Islam Kantor Departemen Agama Kota Surabaya Tahun 2005.
} 
Kemudian Calon pengantin dipanggil dan mereka wajib hadir di KUA untuk diadakan Rafa' (Pemeriksaan Nikah) yang dilakukan oleh PPN KUA, untuk mengetahui siapa calon pengantinnya baik suami atau isteri juga Wali nikahnya, karena pada proses pemeriksaan ini, mereka akan ditanyai satu persatu dan PPN menyesuaikan antara jawaban catin dengan surat yang dikirim mereka kepada KUA, tentang : Nama, Tempat Tanggal Lahir, Alamat, status dan hubungan antara catin laki dan perempuan. Ini dilakukan oleh PPN untuk memastikan adakah hubungan mahram di antara keduanya? Kemudian juga untuk menyesuaikan kebenaran tulisan antara ijazah terakhir yang dijadikan kelengkapan administrasi dengan pencatatan akta nikah, juga ditanyakan hubungan antara catin wanita dengan orang tua wali nikah, apakah betul-betul wali nikah sebenarnya sesuai urutan wali, atau orang tua tiri, orang tua angkat atau bahkan orang lain. Melalui proses rafa' pemeriksaan ini inilah akan diketahui validitas otentisitas adminitrasi nikah dengan kenyataannya. Catin laki-laki, catin wanita dan wali dihadapkan pada PPN di KUA juga di dampingi oleh mudin (imamuddin) pemuka agama untuk membantu dalam pembenaran pengakuan catin dan wali nikah, karen mudin senantiasa bersentuhan langsung dengan masyarakat. Umumnya mudin sangan mengetahui masuarakatnya satu persatu. Sehingga keterangan dan pengetahuan mudin sangat dibutuhkan oleh PPN KUA.

Rafa' merupakan proses pemeriksaan adminitrasi menuju Pencatatan nikah di Kantor Urusan Agama. Pencatatan nikah ini memberikan kemaslahatan (kebaikan) kepada masyarakat Indonesia pada umumnya dan umat Islam pada khususnya untuk menghindari adanya kemafsadatan (kerusakan). Sebagaimana dalam kaidah fiqhiyah:

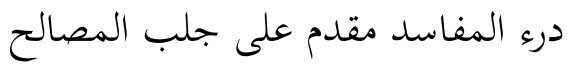

"Menolak kemafsadatan (kerusakan) lebih didahulukan untuk menarik kemaslahatan (kebaikan)". ${ }^{13}$

\section{STUDI ANALISIS PENGARUH RAFA' TERHADAP KEABSAHAN ADMINISTRASI DAN HUKUM PERKAWINAN MENURUT KEPUTUSAN MENTERI AGAMA RI. NO. 298, TAHUN 2003.}

\footnotetext{
${ }^{13}$ Abdul Hamid Hakim, as-Sullam, juz II, hal. 60
} 
Studi Analisis yang kami lakukan tentang : "Studi Analisis Pengaruh Rafa' (Pemeriksaan NIkah) Terhadap Keabsahan Administrasi dan Hukum Perkawinan Menurut Keputusan Menteri Agama RI. No. 298, Tahun 2003.” Yang dilakukan oleh KUA Kec. Jombang sangat administratif dan objektif ini dibuktikan dengan adanya prosedur Administrasi yang dilakukan dan pemanggilan Calon pengantin untuk dilakukan Rafa' (pemeriksaan nikah) dengan menghadirkan wali nikah untuk dilakukan tabayyun cek dan ricek kebenaran adminitrasi dan personelnya, terkait kebenaran pencatatan nama, tempat Tanggal lahir, alamat, pekerjaan, status calon pengantin. Proses penyesuaian ini dilakukan untuk memperkecil adanya kekeliruan dalam pencatatan identitas pengantin dalam dokumen pencatatn nikah di KUA. Selama tidak terjadi perceraian antara kedua Pengantin, Surat Nikah berlaku untuk selamanya sehingga diupayakan pencatatan surat nikah tidak mengalami kekeliruan secara abjad maupun ejaan.

Adapun kebutuhan surat nikah ini terkait dengan syarat adminitrasi yang lainnya, seperti :

1. Untuk pengurusan paspor untuk digunakan perjalan ibadah haji dan umroh

2. Untuk pengurusan Akta Kelahiran

3. Untuk pengurusan hak waris

4. Dasar pencatatn KTP dan Kartu Keluarga

Oleh karena pentingnya kebenaran dalam penulisan identitas pengantin dalam surat nikah, maka diperlukan adanya Rafa' (pemeriksaan nikah) dalam Islam disebut Tabayyun mencari kejelasan menuju kebenaran identitas calon pengantin.

Manfaat adanya Rafa' (pemeriksaan nikah) sangat berpengaruh terhadap keabsahan hukum perkawinan, dikarenakan disitu akan diketahui :

a. Adanya pengakuan status calon pengantin yang dibuktikan secara administratif calon pengantin dibuktikan dengan adanya data form N1, disini akan diketahui apakah perkawinan monogami ataukah poligami, kalau teridentifikasi perkawinan poligami, maka diharuskan memenuhi prosedur administrasi dan batasan maksimum poligami yang diperbolehkan dalam Islam dan hukum positif, dan akan diketahui adanya status calon pengantin 
wanita, maka akan ditemukan praktik perkawinan poliandri yang diharamkan dalam Islam dan hukum perkawinan Indonesia.

b. Asal-usul calon pengantin dibuktikan dengan adanya data form N2, sehingga diketahui orang tua biologis dan orang yang berhak menjadi wali dalam pernikahan karena tercantum nasab.

c. Adanya Surat keterangan wali yang dikeluarkan oleh Pemerintah Desa setempat Sehingga akan diketahui pengakuan wali yang sebenarnya sesuai Nasab. Sesuai pendapat madzhab Syafi'i yang urutan tersebut didasarkan pada ashabah. $^{14}$

d. Adanya persetujuan calon pengantin dibuktikan dengan tandatangan pada form N3 sehingga akad nikah bisa dilangsungkan karena tidak ada unsur paksaan dari orang tua dan pihak lain. Kaarena dalam Islam tiada paksaan dalam ibadah apalagi ada niat menyakiti dalam perkawinan itu diharamkan

\section{PENUTUP}

Berdasarkan pembahasan di atas, Menurut pandangan penulis adanyaRafa' (Pemeriksaan Nikah) ini sangat berpengaruh bahkan menentukan adanya keabsahan hukum perkawinan dalam Islam dan di Indonesia, dalam Islam ditentukan syarat rukun perkawinan sedangkan dalam hukum perkawinan di Indonesia meyertakan kewajiban pencatatan perkawinan di KUA berguna untuk mengontrol adanya kecurangan yang dilakukan oleh oknum yang tidak bertanggung jawab yang akhirnya adalah mencederai tujuan hukum perkawinan. Praktik kecurangan oknum ini terjadi dengan cara memalsukan identitas berupa nama, alamat, stat us, sehingga pelaku ini bebes melakukan praktek perkawinan dimana mana. Melihat kenyataan masyarakat tersebut, maka perlu diadakan Rafa' (Pemeriksaan Nikah) yang berguna untuk meminimalisir adanya kecurangan administrasi, pemalsuan data dan tindakan tindakan merugikan yang berkedok di balik ikatan perkawinan.

\section{DAFTAR PUSTAKA}

Al-Qur'an dan Terjemahnya,

\footnotetext{
${ }^{14}$ Kamal Mukhtar, "Asas-asas Hukum Islam Tentang Perkawinan", hal. 101
} 
Undang-undang Perkawinan di Indonesia tentang, "Dasar-dasar Perkawinan”, .

Keputusan Menteri Agama Republik Indonesia No. 154 Tahun 1991 tentang pelaksanaan Intruksi Presiden Republik Indonesia No. 1 Tahun 1991.

Dirjen Bimais dan Penyelenggaraan Haji, Pedoman Pembantu Pegawai Pencatat Nikah, Jakarta : tahun 2004.

Keputusan Menteri Agama RI. No. 477 Tahun 2004 tentang, "Pemeriksaan Kehendak Nikah".

Peraturan Pemerintah Republik Indonesia No. 9 Tahun 1975 tentang pelaksanaan Undang-Undang No. 1 Tahun 1974 tentang Perkawinan.

Abdurrahman, Kompilasi Hukum Islam di Indonesia, Jakarta : Akademika Pressindo, Tahun 1992.

Keputusan Menteri Agama RI No. 477 Tahun 2004 tentang "Pencatatan Nikah" Diterbitkan Seksi Urusan Agama Islam Kantor Departemen Agama Kota Surabaya Tahun 2005.

Kamal Mukhtar, Asas-asas Hukum Islam Tentang Perkawinan, Jakarta : Bulan Bintang, 1974.

Abdul Hamid, as-Sullam, Surabaya : al-Hidayah, 1998.

Abdurrohman al-Ghozi, Fiqh Munakahat, Jakarta : Kencana, 2012

Tuntunan praktis rumah tangga bahagia, (Sudoarjo : Badan Penasihatan, pembinaan dan pelestarian perkawinan BP4. Prov. Jatim. 